\title{
The Role of Women in Medical Services in the Early Islamic Period
}

\author{
Prof. Dr. Levent Ozturk \\ Faculty of Theology, Department of Islamic History and Arts \\ Sakarya University / TURKEY \\ leventozturk@outlook.com
}

\begin{abstract}
During the time of the Prophet Muhammad, some women took part in medical services to contribute their society, in Mecca and Medina. We found approximately 50 women contributing to their society in terms of medical services. Their medical contributions were generally traditional practices about the daily necessities of their society. Understanding the service provided by these women to their society at that time is very significant in terms of its contribution to the history of folk medicine. The contribution of these women was mainly in the areas of the nursing and assisting the midwifes, prenatal and postnatal care, some surgical operations, caring were wounded in wars, giving soldiers a meal, medical treatment for some diseases and daily injuring, treatment of animal beats, psychological therapy, practicing dietician care and body care, some folkloric treatments of some pediatric diseases, and sexual education. In this paper, I will ground my work on Islamic sources.
\end{abstract}

Keywords: Medical Services, Muslim Women, Sahābiyyāt, Early Islamic Period, Medicine

\section{Introduction}

Human being became always interested in health during the history. In time, some experiences, observations and preferences became bases of medical science. Evaluating the medical situation in history in the light of today's improved medical point we say naturally that former medical information and practices were primitive. However it's certain that all efforts about human health till the present are valuable and the modern-day information is based on very complicated origins (al-Ruhāwī, pp. 40-41; Ibn Abū Usaybia, pp. 11-18).

We all know from ancient sources that some methods of treatment went on during the centuries and there was a greater interaction between cultures and civilizations. Some methods of cure and medicine prospectuses include the same methods and ingredients after long centuries. Continuously India, Mesopotamia and Egypt civilizations influenced one another and following civilizations. The Arabian Peninsula was under the influence of them. Except local practices and interaction period with other civilizations there were no original medical practices in this peninsula and they were under the other civilizations' influence (Ibn Haldūn, pp. 479-480; Jawād Ali, VIII, 388-389).

In this study of medical services provided by women in the reign of the early Islamic period we must indicate that trying to find some practices which is similar to modern-day is all wrong. The most important solution is to describe one special period of history as it is without corcerning today's viewpoint. Our subject must be thought in this manner.

\section{The Nursing and Assisting for the Midwifes}

In the Medinian society, women gave the midwifery service. It must be remembered that in the ancient medical tradition this type of medical services were provided only by men in certain regions. But there is no indication that men, included slaves practiced this kind of services in Arabian society. It can be thought that in Arabian society, slaves were helping their masters at birth as it was in Rome though there is no concrete evidence about this in Islamic sources. Because of the employment of both free and slave women serving at birth, we can conclude that men in Arabian society did not serve for it. Salmā and Sawdah binti Misrāh etc. were outstanding midwives in Medinian society. Sometimes at birth there were several midwives for the patient at the same time. For instance, meanwhile Fātima binti Muhammad was being born Sawdah, Salmā, and some other women were with her (al-Tabarānī, XXIV, 311-312; Ibn Hajar, IV, 274, VIII, 101, 188-189).

It's still not very clear whether the midwives had an ability to guess the birthday or not. In addition to this, it hasn't been known that whether they helped in problematic birth or not. As shown by myths and legends the caesarean section was 
being practiced in ancient times. Yet there is no information in Islamic sources on the subject of caesarean section in the reign of the early Islamic period.

In the Qur'ān it isn't allowed to kill children for fear of starvation (17: 31). This considered as an abortion. It's probable that the advices of the midwives facilitated the abortion operation for Arab women. As Khalīl $b$. Ahmad mentioned, Arabians were taking fetus thrusting their hands into uterus of camel. Because of being forced, the fetus was falling by itself if it wasn't taken. Khalïl b. Ahmad says it was the same for women (Khalïl ibn Ahmad, III, 129, VII, 278).

However we don't know if women at risk were treated or not. Women, who had a miscarriage, may have had the same problems. As for this matter, there is an important narration. After the Hijrah of the Prophet Muhammad, his daughter Zainab also had left Mecca. In her way to Medina some groups of people from Quraish Tribe wanted to trouble her and caused her to fall down from her camel. Zainab was pregnant at that time and being injured she had a miscarriage and died in the following years. At this juncture, it is safe to assume that we can estimate that Zainab suffered from that and couldn't recover and she died in the eighth year of Hijrah (al-Tabarānī, XXII, 433).

Besides this, there were some women suffered from excessive hemorrhages in Medina. Although there are great deals of records saying that women in Medina suffered from these illnesses for many years. There are no others saying that they were cured. The reason of the fact that women in Medina had excessive hemorrhages seems to be ritual circumcision of these women (Ibn Ishāq, p. 308; Ibn Hishām, III-IV, 69; Ahmad ibn Hanbal, VI, 119, 128-129; al-Tirmidhī, Tahāre, 93-96).

\section{Prenatal and Postnatal Care}

It's recorded that Arab women were putting the fresh date to water and drinking its squash. Although some records say that the Prophet Muhammad advised this, it is safe to say that it is known in Medina society before (al-Tabarānī, XXIII, 313).

According to the report narrated by Umm Salama, women, recovering from childbirth were resting under the care of her friends. Moreover, a patient from childbirth was being treated for pimples and marks on their skin with a plant, which called "vers" (Ahmad ibn Hanbal, VI, 300, 303, 304; Abū Dāwūd, 311, 312).

\section{Some Surgical Operations}

Among Arabs both men and women were being circumcised. As stated by various reports some women were processed circumcision. Umm Atiyya was the most famous one (Abū Dāwūd, 137; Ibn Hajar, IV, 46). It seems to be that there is no information as regards how this operation, which had a danger of infection, was processed and what kind instruments were used.

\section{Caring were Wounded People in Wars}

Women companions of the Prophet Muhammad would want to take part in wars. It is seen that their mainly concern about joining wars was first aid and care for soldiers holds our attention.

We all know that Medinians had to fight against Meccans because of their attacks to Medina. In this process Badr, Uhud, Khaibar, Hunain etc. wars took place. Many companions of the Prophet Muhammad were wounded. Some of them were treated while others died. The number of the wounded people during the wars was far too much. Uhud war can be offered as an example. During this war nearly seventy companions became martyr and many of them were wounded. When the archers left the hill the soldiers among enemy power were wounded badly. During Uhud war the helmet of the Prophet Muhammad smashed to pieces and some of these pieces prickled to his face and his face started to bleed. First it was tried to clean with water, but then the reed ash was used to stop it for the reason that bleeding was too dense. As shown by al-Wāqidī the Muslims coming back to Medina tried to treat the wounded by lighting fire in the mosque (al-Wāqıdī, I, 248).

Al-Wāqidī gives information about the number of the wounded people during Uhud war. All Banū Abd al-Ashhal, Banū Sāidah, Ahl al-Hurbā and forty persons from Banū Salima were wounded during the war (al-Wāqıdī, l, 334-335).

When we consider this information we find that there was an intensive process of treatment. Besides wounds of these persons, some serious wounds needed further treatments. Therefore they were taken care closely. For instance Abū Salama b. Abd al-Asad was treated during one month for its exact recovery. This information indicates that there were some serious wounded people at wars and the treatments were not being made in time (al-Wāqıdī, I, 340-341, 343). 
There were a huge number of wounded people during Khaibar war. The first fight at the war started in the lower part of alNatāt. The wounded were brought into headquarters and cured there. In the first clash, fifty persons were wounded in view of arrows of people from Khaibar. Women companions who joined the army were healing those wounds (al-Wāqıdī, II, 646). It can be said that nurse's aide diminished their pain through relieving them and consolation.

In this context as well as Hamna binti Cahsh, Hind binti Amr, Laylā al-Gifāriyyah, Muāza al-Gifāriyyah, Rufayda binti Sa'd, Umm Atiyya al-Ansāriyyah, Umm Ayman, Umm Umāra, Â'isha, the wife of the Prophet Muhammad, and Fātima, his daughter can be mentioned. These women served the wounded people at wars.

There were women who took part in wars in spite of their pregnancy. This fact seems to indicate that these women have great ability of treatment. The wife of Abd Allah $b$. Unays was one of them. She gave birth to her baby on the way to Khaibar and during that war she served well and assured the Prophet Muhammad's approval (al-Wāqıdī, II, 686).

The services of the women companions at wars were not limited to medical services. At the same time they distributed water to soldiers and collected bows. They cared for animals. Sometimes important messages were sent through them. In addition to this, they protected the Prophet Muhammad's life at the risk of their own life. In Uhud and Khandaq wars they transported dead and wounded people to Medina.

It has known that after Uhud war some women took corpses of their relatives to Medina but in the light of the Prophet Muhammad's order they took them back to Uhud. There are some expressions in some women's record like that: "We would take the dead to Medina." (Al-Bukhārī, Jihād, 66, 67; Ibn Kathīr, IV, 42-43 ). If these expressions are not limited to Uhud and Khandaq wars then what can we say about the dead in Khaibar war. Were they also taken to Medina? In that case had they some techniques for protecting dead bodies? Actually there is no clear answer to these questions.

\section{The Supplying of Food for Needy People during the Wars}

One of the important services women made was to supply food for needy people. Umm Atiyya says that as well as treating the wounded she prepared soldiers' meal. Clearly besides medical services they could prepare the army's meal.

That is to say women's food service didn't consist of supplying food one and only. Actually, that service means not to let the soldiers falling ill. As physician Vegetius of Rome made us notice water of soldiers by pointing that drinking dirty water is like drinking poison. In the past it was very common that soldiers were dying due to eating unclean food. Likewise being poisoned and caught intestine infection can be mentioned. For this reason the Prophet Muhammad didn't let his soldiers drink water in Madāin-i Sālih despite their immediate needs in the way of Tabūk.

Further, prepared meal at wars by women gives great strength to the soldiers to resist illnesses. The immediate example in this matter is that of Tabūk war (al-WāqıIĪ, III, 1006-1009). Umm Atiyya al-Ansāriyya was recorded in the sources as a women prepared meal at wars.

\section{Medical Treatment for Some Diseases and Daily Injuring}

Sometimes naughtiness of children, sometimes parents' carelessness caused minor injuries. To illustrate it we can give the example of 'Usāma b. Zaid, who fell down by the door and his face bled. Hence the Prophet Muhammad wanted Á'isha to clean it. As it mentioned in another record Usāma was hurt and Fātima cleaned his face (al-Wāqıdī, III, 1125-1126; Ibn Māja, 1976).

According to some reports (al-Wāqıdī, I, 247-250, 336; Ibn Sa'd, II, 48), bleeding was tried to be stop by absorbing. For instance at Uhud war, Mālik b. Sinān, father of Abū Saīd al-Khudrī, absorbed the blood on the Prophet Muhammad's face to prevent it to be poisoned. The Prophet Muhammad did the same thing when Usāme b. Zaid fall over. In these examples it was aimed to take the blood out of the wound via pumping. It reminds us of "hajāma" in ancient medical treatment and bleeding blood by slitting veins and arteries. In these injuries, it seems that vacuum pots for "hajāma" weren't used. However as far as the reason is concerned we can say that these instruments were not so widespread and it was impossible to use them on the face.

One of the most widespread methods of treatment was branding. Even women carried out this. But the prophet Muhammad didn't approve this and advised to use hot cloth or warmed stones.

The most frequent disease was fevers. In order to reduce fever some water was being poured onto the body. Correspondingly high fever was a widespread disease in Medina because of its climate. The treatment was the same. The 
Prophet Muhammad faced this disease and for its cure he ordered to bring water from various wells, which had different minerals (Ibn Sa'd, II, 232; al-Bukhārī, Maghāzī, 85).

Moreover, there are some record saying that Ā'isha and her elder sister Asmā binti Abū Bakir cured the patients having high fever by using water.

When it comes to diseases whose reasons couldn't be realized, we can say that different methods were being experienced and, trying to be diagnosed. When The Prophet Muhammad was ill Asmā binti Umeys and Umm Salama experienced a different method of treatment from Ethiopia after water didn't make him feel better (al-Bukhārī, Tib, 21; al- Tabarī, 1967: III, 196).

Diarrhea, constipation etc. were tried to cure as well as experiences allowed. Asmā binti Umays was using "Shubrum: euphorbia pithyusa" having an immediate effect as mushily. The Prophet Muhammad is saying that "it's not proper to use it, and then she started to use "senā, senna: cassia angustifolia" (Ahmad ibn Hanbal, VI, 369).

As far as we could conclude there is no clear information on how frequent diseases like being poisoned, fracture, burn etc. were treated though it can be said that they were treated via some similar methods to present day medicine.

\section{Treatment of Animal Bites}

Because of its climate and characteristics there were a lot of scorpions, mice, snakes etc. in Medina. We know that the Prophet Muhammad wanted some detrimental animals to be killed. Motley lizard (in Arabic: wazag), detrimental kind of snakes, scorpion and mouse were some of them. Contrary to his previous ordering to kill all snakes the Prophet Muhammad banned to kill domestic and harmless snakes afterwards (Ibn Māja, 1511, 3228-3231; al-Tirmidhī, 1511-1513, 1515, 3249). However, bites of snakes and scorpions were one of important problems in the Medina society. As a result there was a family being busy with treatment of bites of poisonous animals. It was the member of Hazm family, and especially the mother, Khalidah were expert in treatment of these kinds.

\section{Psychological Therapy: "Rukyah"}

Indeed, there was a method of cure containing prayer and rite in ancient civilizations. This method was being known in Arabian society prevalently. There were foremost persons and famous oracles. "Rukyah" was far more widespread in Medina than Mecca as Jews lived there. Prevalently the Prophet Muhammad banned "Rukyah" but then it was allowed with some changes in its content, including useless things.

Rukyah looks similar to a dialog between doctor and patient that cheers up the patient. Moreover it bears resemblance to psychotherapy. But in ancient civilizations Rukyah included not only psychological treatment but also medicines. It's unknown whether they used these medicines for they were useful or to give a boost to the patient's moral.

All in all we can say that in treatments that time the psychological aspect was important more often than not. There was a therapy aiming the patient to pull himself together and to solve the problems that the evil eye giving rises to. The patient thought of God under the influence of prayer being held. Ā'isha, Asmā binti Umays, Maymūna binti al-Hāris, al-Shifā binti Abd Allah were expert in that kind of treatment (Ibn Māja, 3515; al-Tabarānī, XXV, 43).

\section{Carrying Out Dietician Care and Body Care}

It's clear that one of the most important principles of a healthy lifestyle is eating healthy food regularly. Basic principles of Romanian physicians regarding the health were based on diet and sports more than treatment. As recorded by Ā'isha, women in Arabian society were careful about their weight. They were thin and slight. Furthermore Ä'isha warned young single women putting on weight and advised to be more careful about their health. We know that A' isha and the Prophet Muhammad had a healthy lifestyle and ran sometimes (Ahmad ibn Hanbal, VI, 39-264). As shown by records from Á'isha, people in Arabian society preferred to eat sweet things. It's recorded that some foods were being advised to the people having indigestion in their bellies.

In particular women had trouble with baldness. It is unknown that whether they treated this or not. But it must be remembered that using "hınâ: henna" was prevalent in Arabian society. Today henna is important in hair care. Additionally, Arabs were using wigs to prevent themselves from being seen as bald. 
We all know that there is a tradition called "qaylülah: sleeping in the midday". Some information in the sources says that the prophet Muhammad was sleeping at noon in some of women companions' houses. His aunt Umm al-Fadl was one of them. The others were Rubayyi binti Muawwiz, al-Shifā binti Abd Allah, Umm Atiyya al-Ansāriyya, Umm Harām binti Milhān, Umm Sulaim.

That the Prophet Muhammad slept in some women companions' houses caused some scholars to interpret the situation in different ways. For instance Ibn Qudāme says that the Prophet Muhammad slept in Umm Haram's house as she was his relative. As a matter of fact there is no need to interpret these examples in this way. There is no close relationship between some of these women and the prophet (ibn Qudāma, XIII, 12-13).

But that many of these women being nurses were an important point. It's clear that qaylūlah must be reinterpreted. It cannot be understood as an ordinary sleep only. To illustrate this case we can concider one example. While Ali having a sleep in Umm Atiyya's house he had plucked his arm pit hairs to Umm Shurāhïl, Umm Atiyya's slave (Ibn Sa'd, VIII, 456). We don't claim that they were gymnasiums in Arabian society as well as in Rome. Cause as it has known there is no public bath in Medina. The family had no a bath at home. In addition there were no private toilets at home. But it can be thought that some services like body care could be given in Arabic society. Furthermore Mecca's city plan and administrative model was too similar that of Romanian admintration style. To sum up we would like to say that this subject must be restudied carefully.

\section{Some Folkloric Treatments of Some Pediatric Diseases}

The treatment of angina/tonsil is a method of cure that the sources emphasized it frequently. But it wasn't accepted by the prophet. There are women practicing and helping to this cure. Possibly the wives of the prophet knew this cure. Because there are some records indicating that people go them to cure this disease. This situation may be arising from their positions in the society but saying that they knew this cure is also a possible reason. In this context Umm Qays binti Mihsān is recorded in the sources. We know that the prophet advised some liquids to be taken through the nose in the name of this treatment (al-Bukhārī, Tib, 10, 13; Ibn Abū Shaiba, V, 424).

In the sources it's recorded that Usāme b. Zaid caught smallpox. That the prophet kissed Usāme's face after washing it to show A' 'isha that there was nothing to fear indicates that Medinian society knew smallpox. The record saying that smallpox was seen in Mecca after Abraha's abortive attempt (in A.D. 569) to destroy Mecca seems to mean something different. We couldn't find more information about this in the sources (Ibn Hishām, I-II, 52-54; al-Tabarī, 1900-1907: XXX, 169).

\section{Sexual Education}

Sexual education is a service given by women in Medinian society. To illustrate A' isha gave information to brides about wedding night and family relationship. Especially problems about menstruation, sexuality, unlawful sexual pleasure etc. has aspects about health. So to advice in these matters, the wives of the prophet were foremost.

Umm Salama was one of these women. She was interested in Medinian problems about sexuality as well as menstruation. She let the prophet know some sexual problems influenced women of Medina in view of some prohibitions of Jewish on these matters (Ahmad ibn Hanbal, VI, 305).

Besides, distinguished women of Medina let fresh married couples know the information about wedding night. They advised them to take care to stay healthful. In this context we have no information about their knowledge about getting pregnant or not.

Some women not realizing some of the general principles about family were interested in magic. This kind of attempts was generally related to sexual problems. So to prevent these things both views of the prophet and his wifes gave a piece of advice in Medina society (Ibn Habīb, p. 231).

\section{Conclusion}

In the early Islamic period, women provided significant medical services to the society. This is something different from other cultures in which women were all non-influential in the medical services. However it must be stated that those medical 
services given by women in the time of the Prophet Muhammad were a part of the folkloric medicine. Practices about medicine were not as developed as other cultures and besides their own local experiences they were under other civilizations' influence.

In this study we have found that the number of women practicing medical services was approximately fifty. These acts can be divided into two groups as daily life and war, and we can summarize them as the following:

The nursing and assisting the midwifes, prenatal and postnatal care, some surgical operations, caring who were wounded in wars, the supplying of food for needy people during the wars, medical treatment for some diseases and daily injuring, treatment of animal bites, psychological therapy, carrying out dietician care and body care, some folkloric treatments of some pediatric diseases, warning about hygiene standards, assistance about special women disease and sexual education.

All the information shows that women played an important role in medical services in the Islamic society during the time of Prophet Muhammad, tried to solve the daily problems and medical issues as they would manage at that time.

\section{References}

Abū Dāwūd, Suleimān ibn al-Ashās al-Sijistānī (1969-1974), (d. A.D. 888), Sunan Abū Dāwūd (ed. Izzat Ubayd al-DuāsĀdil al-Sayyid), I-V, Homs.

Ahmad ibn Hanbal (1895), (d. A.D. 855), Musnadu Ahmad, I-IV, Cairo.

Al-Bukhārī, Muhammad ibn Ismāīl (1979), (d. A.D. 870), al-Jāmi‘ al-Sahīh, I-VIII, Istanbul.

Ibn Abū Shaiba, Abdullah ibn Muhammed al-Qūfī (1994), (d. A.D. 849), al-Musannaf fĩ al-Ahādīs wa al-Āsār (ed. Saīd alLihām), I-VIII, Beirut.

Ibn Abū Usaybia (n.d.), (d. A.D. 1270), Uyūn al-Anbā fí Tabakāt al-Atibbā (ed. Nizār Rıdā), Beirut.

Ibn Habīb, Abdulmelik al-Andalūsī (1992), (d. A.D. 852), Kitābu Ādab al-Nisā: Kitāb al-Gāya wa al-Nihāya (ed. Abdulmecīd al-Turkī), Beirut.

Ibn Hajar al-Asqalānī (1992), (d. A.D. 1448), al-Isāba fĩ Tamyīz al-Sahāba (ed. M. Bejāwī), I-VIII, Beirut.

Ibn Haldūn, Abdurrahmān ibn Muhammad (1996), (d. A.D. 1406), al-Muqaddimatu ibn Haldūn (ed. Darwīsh al-Juveydī), $2^{\text {nd }}$ edition, Beirut.

Ibn Hishām, Muhammad ibn Abdulmalīk (1955), (d. A.D. 833), Sīrāt al-Nabī (ed. Mustafa al-Saqqā), I-IV, Cairo.

Ibn Ishāq, Muhammad (1981), (d. A.D. 768), Sīra Ibn Ishāq (ed. Muhammad Hamīdullah), Rabat.

Ibn Kathīr Ismāīl ibn Umar (1981), (d. A.D. 1373), al-Bidāya wa al-Nihāya, I-XIV, Beirut.

İbn Qudāma, Muvaffaquddīn Abū Muhammad Abdullah ibn Ahmad ibn Muhammad (1992), (d. A.D. 1223), al-Mughnī (ed. Abdullah ibn Abdu'l-Muhsin al-Turkī-Abdulfettāh Muhammad al-Hulv), I-XV, $2^{\text {nd }}$ edition, Cairo.

Ibn Māja, Abū Abdullah Muhammad ibn Yazīd (n.d.), (d. A.D. 888), al-Sunan, I-II, Egypt.

Ibn Sa'd, Muhammad (1985), (d. A.D. 884), al-Tabaqāt al-Qubrā, I-IX, Beirut.

Jawād Ali (1976-1978), al-Mufassal fị Tārīh al-Arab Qabl al-Islām, I-X, Beirut.

Khalīl ibn Ahmad (1988), (d. A.D. 791), Kitāb al-Ayn (ed. Ibrāhīm al-Sāmarrāī), I-VIII, Beirut.

Al-Ruhāwī Ishāk ibn Ali (1992), (d. A.D. First decades of IX. century), Ādab al-Tabīb (ed. Merīzen Saīd Merīzen Asīīi), Riyād.

Al-Tabarānī, Abū al-Qāsim ibn Ahmad (n.d.) (d. A.D. 971), al-Mu'jam al-Kabīr, l-XXV, Beirut.

Al-Tabarī, Abū Ja'far Muhammad ibn Jarīr (1967), (d. A.D. 922), Tārīkh al-Tabarī (ed. Muhammad Abū al-Fadl Ibrāhīm), I$\mathrm{XI}, 2^{\text {nd }}$ edition, Beirut. 
Al-Tabarī, Abū Ja'far Muhammad ibn Jarīr (1900-1907), (d. A.D. 922), al-Jāmi' al-Bayān fĩ Tafsīr al-Qur'ān, l-XXX, Egypt. Al-Tirmidhī, Muhammad ibn Īsā al-Dahhāk (1975-1978), (d. A.D. 892), al-Sunan al-Tirmidhī (ed. Ahmad Muhammad Shākir) Cairo.

Al-Wāqidī, Muhammad ibn Omar (1966), (d. A.D. 822), Kitāb al-Maghāzī (ed. Marsden Jones), I-III, Beirut. 